\title{
CUSTOMER SATISFACTION IN ONLINE SHOPPING: A CASE STUDY OF BANGKOK URBAN AREA
}

\author{
Irina V. Onyusheva \\ Jatuporn Thongaim
}

Stamford International University, Thailand, Bangkok

This study aims to measure customer satisfaction in online shopping. Along with the increasing usage of the Internet, e-commerce has emerged as a relatively new sales channel in Thailand. Consumer satisfaction and reputation are most important parts of online shopping, both contributing greatly to future demand growth. Trust in online shopping is the major difficulty due to inability to touch the product before purchasing. This factor can also effect customer satisfaction and customer behaviour in relation to various products and services. The purpose of this research is achieved by means of using the online customer survey in Bangkok urban area, Thailand. Some recommendations are addressed to online retailers, namely, it is offered to take more responsibility for the online shopping process so that to make it more admired and trustworthy.

Keywords: e-commerce, online shopping, customer satisfaction, Internet shopping, customer behavior, Bangkok.

\section{Introduction}

In Thailand, e-commerce is still evolving, and the growing number of retailers operating in the online shopping sector is making it a truly competitive market these days. It

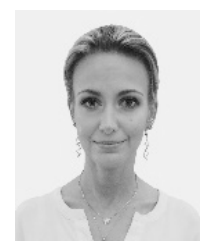

Irina V. Onyusheva

$\mathrm{PhD}$ in Economics, Dr.h.c. of IANH, Associate Professor, Corresponding Member of Academy of Pedagogical Sciences of Kazakhstan, Academician of International Informatization Academy, member of the Editorial Board of the 'Polish Journal of Management Studies' (Scopus, SJR, WoS).

Research Field And Scientific Interests: formation, ensuring and increasing economic competitiveness on both micro- and macro- levels; human capital development; HR management; knowledge economy; project management.

She is the author of more than 70 research publications, author of an individual scientific monograph named "Human capital in context of national economic competitiveness: formation factors and development prospects»" (2015) awarded as "Best educational edition in economic field" in the framework of the XXVI international book fair of educational publications (Sochi, Russia, October 8-11, 2015), and Gold medal "European Quality" (ESIC, Germany, Russia, April 4, 2016).

E-mail: irina.onyusheva@stamford.edu

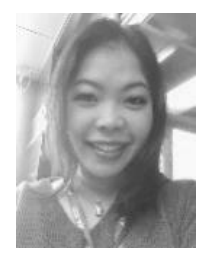

Jatuporn Thongaim

Stamford International University, International MBA Program

Interests - Strategic Management, Strategic Marketing, Consumer Behavior, Global Markets

E-mail: chatu_town@hotmail.com 


\section{CUSTOMER SATISFACTION IN ONLINE SHOPPING}

is therefore essential for these companies to continuously develop their online activity to remain competitive and attract new customers.

The purpose of this paper is to explain the relationship between trust, perceived risk, shopping enjoyment, site design quality and online purchase intention. Customer satisfaction is the consequence of experiences during various purchasing stages: needing something, gathering information about it, evaluating purchasing alternatives, actual purchasing decision, and post-purchasing behavior. Do advertisements, product quality, brand, shopping experiences relate to customer satisfaction in online shopping? Shopping for products online has become a reasonable alternative for millions of consumer since in many cases it is more comfortable than conventional shopping, while the latter often means increased level of anxiety, crowds in a mall, traffic jam, limited time, problems with finding a parking space etc.

Globally, shoppers are gaining tremendous benefits from purchasing goods and services from the cyberspace. The Internet permits the 24/7 and 365 days availability of goods and services at the minimum cost. Surplus-seeking consumers and retailers are always searching for the markets that are more economically efficient, and online purchasing is definitely one of them (Taweerat et al., 2014). The Internet offers benefits which help consumers become more efficient and effective in shopping. Consumer efficiency can be enhanced in online shopping because it provides quicker access to product-related information, thus saving consumers' time, efforts and money (McGaughey \& Mason, 1998). Nowadays, products that are being marketed through the Internet can be classified into two groups. The first group of products contains the items that consumer do not need to see in person before purchasing. These products include everything what can be purchased on a website, via Instagram or Facebook and also scanned goods can be evaluated by using just text, pictures and other digitally communicable information. This group of products ideally suits Internet shopping, since in relation to these products Internet could both its functions transaction and communication ones. The second group of products is termed as experience products, the items that consumers prefer to see and touch while purchasing, such as clothes, groceries and electronic products. This group of products is not suitable for Internet shopping since basic information about these products' features may not be sufficient for consumers to engage in purchase transactions (Haque \& Khatibi, 2007).

The aim of this study is to define the determinants of how people shop online. The objective of this study is to examine the relationship between online shopping factors and customer satisfaction. More specific objectives of this study include: 1) to identify the factors affecting online customer satisfaction, and 2) to examine the relationship factors of the online customer satisfaction, directly related to customers, such as advertisements, product quality, brand, shopping experiences etc.

\section{Literature review}

\section{Theoretical background}

Business-to-Business (B2B) e-commerce is "online businesses selling to other businesses" (Laudon \& Traver, 2008).

Business-To-Consumer (B2C) e-commerce is "online businesses selling to individual consumers" (Laudon \& Traver, 2008). 
Customer satisfaction is when products and services meet the expectations of consumers. It is very important for consumers to be satisfied with products and services provided by a particular website as satisfied customers are more likely to be loyal and make repetitive purchases which will increase profitability of that particular e-commerce company. In this research, satisfaction which is used as the term for outcome by comparing preliminary expectation and the perceived performance for each antecedent factor in order to measure the attitude (satisfaction/pleasing) of the respondents for each of those factors (Taweerat et al., 2014).

E-commerce means conducting business via the Internet, covering such activities as information searching, information sharing, purchasing or exchanging products and services; and also maintaining customer relationship without face-to-face meetings, unlike it is with traditional transactions. Often e-commerce is wrongfully perceived as a way of doing business between web retailers and web end customers but rather e-commerce encompasses an entire range of conducting online business whether it is the interaction between businesses, or business and customers, or business and government (Taweerat et al., 2014).

\section{Theory}

According to (Kotler \& Keller, 2009), a buyer goes through five stages while making a purchase decision. These stages are best explainable on an example when a buyer goes for buying costly items, such as a house, a car, diamond jewelry etc. However, in case of everyday purchases, consumers may not go through all these stages, since some commodities do not require such information. In simple cases purchasing decision is based on buyer's previous experience, for example, their past visit to a store. These stages are (Figure 1): "problem recognition, information search, evaluation of alternatives, purchase decision, and purchase behavior" (Kotler \& Keller, 2009).

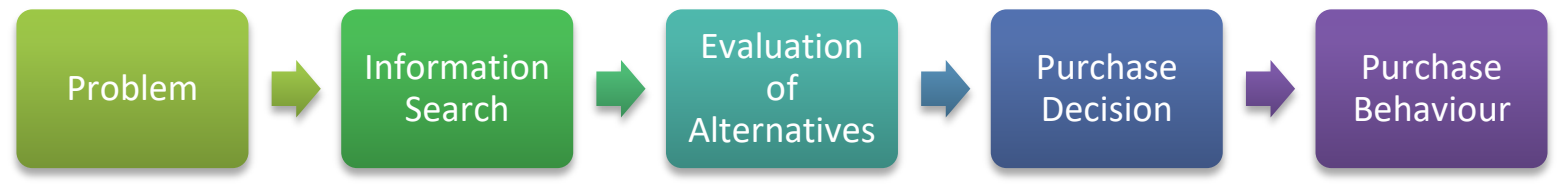

Figure 1. Five stages in modelling the buying process

(Source: Kotler \& Keller, 2009)

In addition, many marketing activities are now much more technologically advanced due to the increasing expansion of online marketing tools (O'Connor \& Galvin, 2001). Companies are now using the Internet to build closer relationships with consumers and marketing partners. Besides competing within traditional marketplaces, they now have access to exciting new market spaces. Moreover, through the Internet, consumers can learn about the design, ways to order, and payment options for the offered products and services, without 


\section{CUSTOMER SATISFACTION IN ONLINE SHOPPING}

leaving home. And later, thanks to express delivery, they can receive their purchases in a relatively short time.

Theory of Loyal Behavior

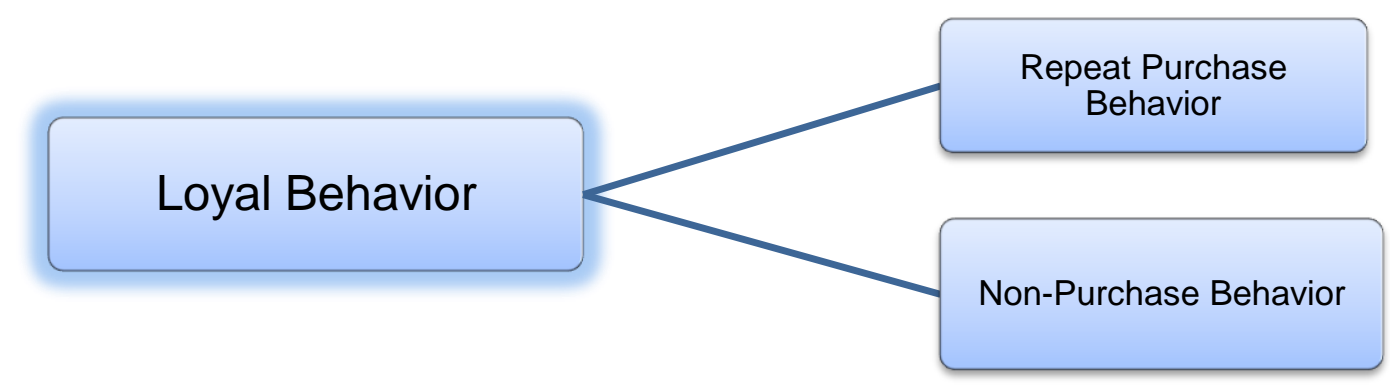

Figure 2. Theory of Loyal Behavior

(Source: Lam, 2005)

According to the theory of loyalty behavior, brand loyalty is generated from the information, perceived utility, product availability and consumer experience.

For this study, word-of-mouth (WOM) will be used as the key information factor since WOM tends to be an influential communication channel among customers in the recent years.

Perceived utility here stands for perceived value of a product or a service which are not only evaluated by their utility but also with consideration of some others aspects (Omanga, 2010). Product availability, as applied here, means convenience of delivery, related first of all to distribution channel. Lastly, consuming experience is related to customer attitude towards purchasing (Lam, 2005) and also satisfaction with products and services.

Word-of-Mouth (WOM)

According to (Lam, 2005), WOM is defined as a communication about particular products and services among friends, family and other potential buyers from the closer circles of the existing client. Moreover, WOM is as a non-commercial information source, since it belongs to interpersonal communication, having the power to affect not only customers' purchasing decisions but also brand attitude overall.

\section{Determinants of the repeated purchase intentions}

Repeated purchase intention refers to the subjective probability that a customer will continue purchasing a product from the same online seller. Thus, initial purchase intention reflects the likelihood that a potential customer will purchase from an online seller for the first time at a given point in time. Comparing returning customers with the potential ones, the former are better in evaluation of information on the product and of the online store's other 
attributes since they already have some experience with this seller. Moreover, motivation behind a consumer's initial purchase from an online store is different from the motivation behind the repeated purchase.

\section{Perceived risk}

Perceived risk is a multidimensional construct. At least four dimensions of perceived risk should be mentioned here, namely: financial loss, product performance, privacy and product delivery.

Financial risk refers to a financial loss due to hidden costs, higher than expected maintenance costs or lack of warranty in case of faults.

Performance risk refers to the probability that a product purchased will not function as it was expected to.

Privacy risk is the potential loss of control over one's personal information.

Product delivery risk refers to the possibility of suffering a loss due to the online seller's failure to deliver the product in a timely manner and/or in a good condition.

Trust and risk are the most important constructs in consumer purchasing decision when it comes to e-commerce, and they are also the key to building relationships with customers online.

\section{The Main Impact Of Customer Satisfaction On Online Purchasing}

It is always interesting to measure customer satisfaction in the context of e-commerce since this factor will always define the success of online vendors. The factors motivating the youngsters to shop for commodity products in the cyber-space examined include: attitudes, demographic factors, personal characteristics and purchasing decision perceptions. The factors influencing online consumer purchasing decisions include:

- product understanding (product perception): price, product quality and product variety;

- shopping experience: attributes of time, convenience and product availability, efforts taken, lifestyle compatibility and also playfulness/enjoyment of the shopping process;

- customer service: vendor responsiveness, assurance and reliability.

- consumer risk: economic, social, performance, personal and privacy risks.

\section{Thailand E-Commerce Case Study}

Table 1. Key statistical information (as of July 2016)

(Source: Internet Live Stats, www.InternetLiveStats.com)

\begin{tabular}{|l|c|}
\hline Internet Users in Thailand (2016) & $29,078,158$ \\
\hline $\begin{array}{l}\text { Share of Thailand's population } \\
\text { (penetration rate) }\end{array}$ & $42.7 \%$ \\
\hline Total population & $68,146,609$ \\
\hline Share of the world Internet users & $0.8 \%$ \\
\hline Number of the Internet users worldwide & $3.424,971,237$ \\
\hline
\end{tabular}




\section{CUSTOMER SATISFACTION IN ONLINE SHOPPING}

With $42.7 \%$ (see Table 1) of total population being active Internet users (and this is data as of 2016, today the number should be higher), e-commerce in Thailand is nothing but lucrative. While this market is still at the stage of formation, the country has ruled the ecommerce scene in the whole Southeast Asia for quite some time by now. As expected, the ecommerce market in Thailand will continue to grow for several years more. In 2017 it generated the revenue in the amount of of $\$ 2,945$ million.

However, this tremendous growth potential coupled with rapidly evolving e-commerce scenario is likely to result in well-defined trends of the industry's development. So, here's an expert summary on what to wait from Thailand e-commerce in the near future.

\section{E-Commerce Market Growth}

E-Commerce in Thailand grew by $15-20 \%$ in 2016 alone. According to some expert opinions, this growth rate is not likely to decrease anytime soon. As per one of the leadering marketing research firm, e-commerce penetration in the country would reach $21.7 \%$ in 2017 and then $24.5 \%$ by 2121 (Internet Live Stats, 2016). Another interesting aspect of ecommerce growth in this region is the growing preference for purchasing electronic goods online. Sales of electronics and media contributed the largest revenue share in 2016, followed by toys, hobby commodities \& DIY. This trend is likely to continue in the nearest several years. High Internet penetration rate and increase of disposable income are the two major factors propelling e-commerce growth in the country. Moreover, government initiatives and support play a significant role in this development.

\section{Online payments}

Mobile payments is another crucial area which would be interesting to observe, as mobile devices are the leading traffic source for e-commerce purchases in Thailand, especially in its rural areas. With the leading players like Line Pay, MOBIAMO, PromptPay, PayPal etc. are aggressively fighting to capture their market share, the number of mobile transactions are likely to experience steady growth in the coming two or three years. As per market research experts' opinions, mobile payment transaction value is expected to display on average $72.3 \%$ yearly growth in the next five years. With so many developments in the online payments' segment, one can expect a decrease in the volumes for the Cash-onDelivery method and increase in the online payments during 2018-2019.

\section{Brand Loyalty}

At such a highly competitive market segment as e-commence where brand loyalty is constantly fluctuating, customer engagement and creating unique user experience is of utmost importance for most online brands. Thus, reinventing the brand to create an edge over the competition is of high priority for online businesses. Proprietary pricing, niche targeting and creating a one-of-a-kind shopping experience is going to take the front seat for many brands in the coming years. A curious trend to look for is chatbots which is an attempt to create a more humane shopping experience with its 24/7 support and more personal shopping experience offered to consumers online.

\section{Logistical Growth}

Logistics remains to be one of the major challenges for e-commerce in Thailand. While e-commerce as such is an industry highly dependent on the efficience of the available 
delivery systems (national or private ones), the country is still in its nascent stage when it comes to e-commerce logistics. The international logistics giant DHL entered Thai market only last year, thus, e-commerce still has a huge share of its logistics nearly totally uncovered, especially when it comes to rural areas. However, the increasing demand for more organized and advanced logistical support as well as the rising popularity of one-day delivery concept would certainly motivate the development of this sector too.

\section{Research Problem, Goal and Objectives}

Online marketing has gained a lot of importance under today's marketing conditions. The problem area of this study is consumer satisfaction and also consumer attitudes towards online shopping, determining the factors that influence customers while they are shopping online. These factors would help marketers formulate their strategies regarding online marketing.

The main goal of this research is to develop and offer e-commerce activities concerning consumer satisfaction in the course of online shopping.

To achieve this central goal research, the following objectives have been identified:

To study the satisfaction level of customers in the course of online purchases.

To study the consumer satisfaction level by the services provided in the course of online shopping.

To analyze the specific reasons why customers are purchasing products online.

\section{Research Methods}

The research methodology is conducting a questionnaire on a sample of online shoppers. This questionnaire comprised of the three parts:

In the first part, the respondents were asked to provide their basic information including gender, age, income and occupation. Customer shopping behavior was in the focus of part two, in which the respondents were asked to specify the types of products they buy online, the frequency with which they go online shopping, and their online shopping expenditures. In part three, the respondents were asked to evaluate online shopping attitudes and behavior, the perceived risk level as well as the level of satisfaction.

For the first two parts, a nominal scale was used, and for the last part, a five-point Likert scale, ranging from 1 to 5 (from "strongly disagree" to "strongly agree") was used. These questionnaires were distributed among Bangkok customers who confirmed they had some experience with online shopping (Pusaksrikit, 2015).

\section{Research Findings}

Table 2 below describe the factors of behavior and satisfaction of customers in the course of online shopping. It also indirectly explains the factors that impact the customers who normally purchase online.

\section{External Environment}

Environment refers to those contextual factors that impact consumers online shopping attitudes and behavior. These factors may, for example, increase the transaction costs for a consumer, thus decreasing their intention to revisit a specific online store. 


\section{CUSTOMER SATISFACTION IN ONLINE SHOPPING}

\section{Demographics}

Demographics include such variables as age, gender, level of education, income, and time spent online. It is quite obvious that online population overall is relatively younger, more educated, wealthier, although the gaps between generations in this regard are gradually closing. However, once people are actually online, demographics does not seem to be the key factor affecting their purchase decisions or shopping behavior.

\section{Personal Characteristics}

We can state preliminary that there is a group of specific customer features that may influence their online shopping attitudes and behavior, such as their Internet knowledge, need for specificity, and cultural environment.

Table 2. Factor of influence in the course of online shopping

(Source: Zhang, 2014)

\begin{tabular}{|c|c|}
\hline Variable types & Factors \\
\hline Independent & External environment \\
\hline Independent & Demographics \\
\hline Independent & Personal characteristics \\
\hline Independent & Vender/service/product characteristics \\
\hline Independent & Website quality \\
\hline Dependent & Attitude towards online shopping \\
\hline Dependent & Intention to shop online \\
\hline Dependent & Decision-making /info-seeking \\
\hline Dependent & Online purchasing \\
\hline Dependent & Consumer satisfaction \\
\hline
\end{tabular}

\section{Vender/Service/Product Characteristics}

The relationship between vender/service/product characteristics and other factors. Vender/service/product characteristics refer to the features of the Internet stores, and of the products they sell, and the service they provide to support transactions. These factors are found to influence online shopping attitudes and behavior significantly.

\section{Website Quality}

A variety of factors related to website quality have been demonstrated to significantly influence consumers' online shopping attitudes and behavior. Better website quality can persuade the consumer to complete transactions smoothly and attract them to revisit the same Internet store. In contrast, worse quality of a website would hinder their online shopping moves.

\section{Attitudes Towards Online Shopping}

Consumers' attitudes towards online shopping have gained a great deal of attention in the empirical literature. It is generally believed that consumer attitudes will affect their intention to shop online and eventually would predetermine whether a transaction is made or not. 


\section{Intention to Shop Online}

Consumers 'intention to shop online refers to their willingness to make purchases in an Internet store. Commonly, this factor is measured by consumers' willingness to buy and later return for additional purchases.

\section{Online Shopping Decision Making}

Online shopping decision-making includes information-seeking, comparison of alternatives, and then - making a choice. The results from this factor directly influence consumers' purchasing behavior. In addition, there appears to be an impact on users' satisfaction too.

\section{Online Purchasing}

This refers to consumers' actions when it comes to the time of placing order and paying. This is the most substantial step in online shopping activities, with most empirical research using the measures of frequency (or number) of purchases and the cost of online purchases as the measures of online purchasing. Other, more like alternative, studies have used such measures are unplanned purchases and/or the Internet store sales.

\section{Consumer Satisfaction}

Consumer satisfaction can be defined as the extent to which consumers' perceptions of the online shopping experience confirm their preliminary expectations. Most consumers form expectations of a product, vendor, service, and quality of the website that they patronize before engaging in the actual process of online shopping. These expectations influence their attitudes and intentions to shop at a certain Internet store, and consequently their decisionmaking processes and purchasing behavior. If expectations are met, customers achieve a high degree of satisfaction, which, in turn, influences their online shopping attitudes, intentions, all further decisions, and purchasing activity positively. In contrast, dissatisfaction is negatively associated with all four variables.

\section{Discussion}

The results summarized in Table 2 indicate that the experience in purchasing has its several significant factors of influence, while the dependent variables detected are as follows: Attitude towards online shopping, Intention to shop online, Decision-making/info-seeking, Online purchasing and Consumer satisfaction. The independent factors detected in this study are: External environment, Demographics, Personal characteristics, Vendor/service/product characteristics and website quality. The independent factor in this particular case means that these factors do not affect purchasing decisions in the course of online shopping that much.

At the same time, experienced clients tend to be less concerned about reliability and responsibility, and this indirectly confirms their confidence in receiving what has been promised; instead, website information quality and appropriate pricing have gained their interests. This finding is consistent with the study of (Bhatnagar et al., 2000) who stated that those who have ever purchased online at least once were less concerned with customer service, and also responsibility and reliability. Same applies to a variety of consumer risk issues such as form of payment, credit card security, and confidentiality. Based the 


\section{CUSTOMER SATISFACTION IN ONLINE SHOPPING}

respondents' suggestion, the authors recognize that these differences root mostly from the fact that the respondents who have already made the transaction are more familiar with purchasing online so they worry less about the security.

In addition, the respondents who have never purchased online mainly pay their attention to such issues as security and service (and also - reliability, responsibility, assurance, empathy) while pricing, interestingly, has more influence in consideration since the issue of price is not as vital as issue of security.

Consumers' trust and perceived risk have strong impacts on the purchasing decisions of online clients. Consumers' disposition to trust, reputation of a particular website, privacy concerns, security concerns, quality of information posted online and also company's reputation overall have strong effects on Internet consumers' trust in a particular website. Interestingly, the presence of a third-party does not strongly influence consumers' trust.

\section{Conclusion}

The increasing use of the WWW as a $\mathrm{B} 2 \mathrm{C}$ commercial tool raises interest in understanding the key issues in building relationships with customers on the Internet. Trust is believed to be the key to these relationships. Given the differences between a virtual and a conventional marketplace, antecedents and consequences of trust in the process of purchasing needs some re-examination. This research identifies a number of key factors related to trust in the $\mathrm{B} 2 \mathrm{C}$ context and proposes a framework based on a series of underpinning relationships among these factors. The findings in this research suggest that people are more likely to purchase from the web if they perceive higher degree of trust in e-commerce and have more experience in using the web overall. Customers' trust levels are likely to be influenced by the level of perceived market orientation, site quality, technical trustworthiness, and user's web experience. People with higher level of perceived site quality seem to have higher level of perceived market orientation and trustworthiness towards e-commerce. Furthermore, people with higher level of trust in e-commerce are more likely to participate in it more actively. Positive word-of-mouth, money-back warranty and partnerships with well-known businesses are ranked as the top three most effective risk reduction tactics. These findings complement the previous findings on e-commerce and shed more light on how to establish a trust relationship with one's clients online.

\section{References}

Bhatnagar, A., Misra, S. \& Rao, H. (2000). On risk, convenience, and Internet shopping behavior. Communications of the ACM, 43: 98-105, 2000.

Haque, A. \& Khatibi, A. (2007). The Impact of internet marketing on customer satisfaction: A study Malaysian perspective. Journal of Mobile communication, 9 (121).

Kolter, P. \& Keller, L.K. (2009) Marketing Management. (13th edition). New Jersey: Pearson Education Ltd.

Lam, D. (2005). True Value of Brand Loyalty. Asia Pacific Advances in Consumer Research, 7.

Laudon, K.C., \& Traver, C.G. (2008). E-Commerce: business, technology, society (4th edition). New Jersey: Pearson Education Ltd.

McGaughey R, \& K. Mason, (1998). The internet as a marketing tool. Journal of Marketing Theory and Practices, 6.

O'Connor, J. \& Galvin, E. (2001). Marketing in the Digital Age. (2nd edition). Harlow: Financial Times/Prentice Hall. 
Omanga, L. K. (2010). Determinates of Brand Loyalty in Cosmetic Products: A Case of Selected Salons in Nyeri Town. Nyeri Town: Kenyatta University.

Pusaksrikit, T. (2015). The Perceived Risks and Customer Dissatisfaction of Online Shopping - a Survey of Thailand Market.

Taweerat J, Settapong M, Navneet M and Jessada S. (2014). The impact of customer satisfaction on Online Purchasing: A case study analysis in Thailand. Journal of Economics, Business and Management, 2 (1).

www.InternetLiveStats.com

Paper submitted

Paper accepted for publishing

Paper published online
11 December 2017

19 February 2018

30 March 2018 